\title{
Autonomous Growth of a Human Neuroblastoma Cell Line Is Mediated by Insulin-like Growth Factor II
}

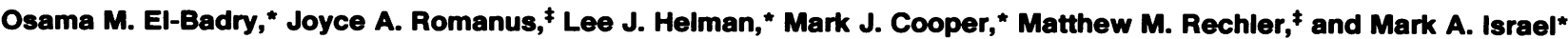
${ }^{*}$ Molecular Genetics Section, Pediatric Branch, National Cancer Institute, and ${ }^{\ddagger}$ Growth and Development Section, Molecular, Cellular, and Nutritional Endocrinology Branch, National Institute of Diabetes and Digestive and Kidney Diseases,

National Institutes of Health, Bethesda, Maryland 20892

\begin{abstract}
Insulin-like growth factor II (IGF-II) mRNA was increased in two of eight neuroblastomas and in eight of eight pheochromocytomas, tumors of the adrenal medulla that occur in childhood and adulthood, respectively. RNA encoding the type I IGF receptor, the receptor thought to mediate the mitogenic effects of IGF-I and IGF-II, also was uniformly expressed in these cells. To assess the role of IGF-II in the growth of these tumor cells, we have used the SK-N-AS cultured neuroblastoma cell line, which can be continuously propagated in mitogen-free medium, as a model system. Our results strongly suggest that IGF-II, synthesized by SK-N-AS cells and acting through type I IGF receptors, contributes to the autonomous growth of this tumor cell line. (a) SK-N-AS cells synthesized large amounts of IGF-II RNA and secreted > $50 \mathrm{ng} / \mathrm{ml}$ of IGF-II (as determined by specific radioimmuno- and radioreceptor assays). Little, if any, IGF-I RNA or immunoreactive IGF-I were detected. (b) SK-N-AS cells possess type I IGF receptors. (c) Exogenous IGF-I and IGF-II stimulated DNA synthesis in SK-N-AS cells, and this stimulation was abolished by a blocking antibody to the type I IGF receptor. (d) This anti-receptor antibody also abolished the multiplication of SK-N-AS cells in the absence of added mitogens. We conclude that IGF-II is an autocrine growth factor for SK-N-AS cells and suggest that this mechanism may contribute to the growth of some adrenal medullary tumors.
\end{abstract}

\section{Introduction}

Insulin-like growth factor I (IGF-I) ${ }^{1}$ and IGF-II are chemically similar peptides that have substantial amino acid sequence homology with insulin (1). IGF-I is thought to mediate the growth-promoting effects of pituitary growth hormone during postnatal growth (2-5). The physiologic role of IGF-II is less well understood. Several observations suggest that IGF-II is

A preliminary account of this work was presented at the University of California, Los Angeles Symposium on Molecular and Cellular Biology, January 1989.

Received for publication 10 February 1989 and in revised form 11 April 1989.

1. Abbreviations used in this paper: aFGF and bFGF, acidic and basic fibroblast growth factors; ECGF, endothelial cell growth factor; EGF, epidermal growth factor; G-CSF, granulocyte colony-stimulating factor; IGF, insulin-like growth factor; MTT, 3-(4,5-dimethylthiazol-2yl)-2,5-diphenyltetrazolium bromide; PDGF, platelet-derived growth factor; TGF, transforming growth factor.

The Journal of Clinical Investigation, Inc.

Volume 84, September 1989, 829-839 involved in fetal growth and development: IGF-II levels are 20 - to 100 -fold higher in fetal rat serum than in maternal serum (6); fetal rat fibroblasts secrete substantial amounts of IGF-II but little IGF-I, a situation that is reversed in fibroblasts from 50-d-old rats (7); IGF-II mRNA is expressed at substantially higher levels in rat $(8,9)$ and human $(10-15)$ fetal tissues than in the corresponding adult tissues; and IGF-II mRNA is considerably more abundant than IGF-I mRNA in many human fetal tissues $(13,15)$.

The IGF-II gene also is expressed at high levels in several human embryonal tumors including Wilms' tumor, rhabdomyosarcoma, and hepatoblastoma relative to adult kidney, skeletal muscle, and liver, the corresponding mature tissues in which these tumors arise $(10,11,16)$. Because of the high levels of IGF-II expression in the developing fetus and in these embryonal tumors, we considered the possibility that IGF-II might contribute to the neoplastic proliferation of neuroblastoma, a highly malignant tumor that is thought to arise in cells of the developing sympathetic nervous system $(17,18)$. In the present study, we demonstrate that a cell line derived from a human neuroblastoma, SK-N-AS, grows continuously in mitogen-free medium, produces IGF-II, and possesses type I IGF receptors that are capable of mediating the mitogenic activity of IGF-II. A type I IGF receptor antagonist, $\alpha$-IR-3, blocks the mitogenic effects of exogenously added IGF-I and IGF-II and inhibits the growth of SK-N-AS cells in mitogen-free medium. These results strongly suggest that IGF-II, acting through type I IGF receptors, is an autocrine growth factor for SK-N-AS cells. The presence of IGF-II mRNA and type I IGF receptor mRNA in some neuroblastomas and in pheochromocytomas, tumors of the adult adrenal medulla, suggest that IGF-II also may be an autocrine growth factor for some tumors of the adrenal medulla.

\section{Methods}

\section{Cell culture}

Stock cultures of SK-N-AS cells (19-21; gift of Dr. L. Helson, ICI Americas, Wilmington, DE) were grown in monolayer culture for several passages in medium containing $10 \%$ fetal bovine serum. To determine whether SK-N-AS cells were able to grow in medium without serum, cells were transferred directly into serum-free N2E medium (described below) containing insulin $(1 \mu \mathrm{g} / \mathrm{ml})$. After several passages, insulin was omitted from the medium, and the cells were continuously propagated in mitogen-free N2E medium. SK-N-AS cells were fed every 3-4 d and were passaged weekly at a ratio of 1:10. Cells were routinely fed $24 \mathrm{~h}$ before harvest for experiments.

N2E medium was modified from the previously described N2 medium $(22,23)$ by the omission of insulin and a decrease in the transferrin concentration. It contains transferrin $(1 \mu \mathrm{g} / \mathrm{ml})$, selenium $(30$ $\mathrm{nM}$ ), progesterone ( $20 \mathrm{nM})$, and putrescine $(100 \mu \mathrm{M})$ (Sigma Chemical Co., St. Louis, MO.) added to a basal medium of Ham's F12 and 
Dulbecco-Vogt's modified Eagle's medium (50:50, vol/vol) supplemented with sodium bicarbonate $(1.2 \mathrm{mg} / \mathrm{ml})$, Hepes buffer $(15 \mathrm{mM})$ (Biofluids, Rockville, MD), penicillin $(50 \mathrm{U} / \mathrm{ml})$, streptomycin (50 $\mu \mathrm{g} / \mathrm{ml})$, and L-glutamine $(2 \mathrm{mM})$. Culture dishes were pretreated with poly-D-lysine (100 $\mu \mathrm{g} / \mathrm{ml})$ (Sigma Chemical Co.), and human fibronectin $(5 \mu \mathrm{g} / \mathrm{ml})$ (Bethesda Research Laboratories, Gaithersburg, MD) was added to the medium at the time of plating. Medium used for refeeding the cultures did not contain fibronectin.

\section{Materials}

Peptides. IGF-I ( $\mathrm{Thr}^{59}$ analogue) was purchased from Amgen Biologicals (Thousand Oaks, CA). Rat IGF-II (7.5 kD) was purified from media conditioned by the BRL 3A rat liver cell line (ATCC CRL 1442) as described by Greenstein et al. (24) and kindly provided by Dr. S. P. Nissley (National Cancer Institute). Recombinant human IGF-II was a gift of Dr. M. C. Smith (Eli Lilly Co., Indianapolis, IN). The following growth factors were purchased from the indicated commercial sources: transforming growth factor- $\beta_{1}$ (TGF- $\beta_{1}$, human platelets, $97 \%$ pure), platelet-derived growth factor (PDGF, human platelets), and acidic fibroblast growth factor (aFGF, bovine brain, 95\% pure), $R$ and $D$ Systems, Inc., Minneapolis, MN; basic fibroblast growth factor (bFGF) and granulocyte colony-stimulating factor (G-CSF, recombinant, 95\% pure), Amgen Biologicals; epidermal growth factor (EGF, mouse submaxillary gland, receptor grade) and endothelial cell growth factor (ECGF, bovine brain, $90 \%$ pure), Collaborative Research, Inc., Bedford, MA.

Antibodies. Rabbit antiserum to human IGF-II was a gift of Dr. $\mathbf{R}$. Sportsman (Eli Lilly Co.) Mouse monoclonal immunoglobulin $\alpha$-IR-3 $\left(95 \%\right.$ IgG- $\left.\kappa_{1}\right)(25,26)$ was provided by Dr. S. Jacobs (Burroughs Wellcome Co., Research Triangle Park, NC). MOPC-21 (IgG- $\kappa_{1}$ ) was purchased from Cappel Laboratories (Westchester, PA). Rabbit antiserum to human IGF-I (2) was provided by Drs. J. J. Van Wyk and L. E. Underwood (University of North Carolina, Chapel Hill, NC) and distributed by the National Hormone and Pituitary Agency (Baltimore, MD).

Radioligands. ${ }^{125} \mathrm{I}-\mathrm{IGF}-\mathrm{I}(267 \mathrm{Ci} / \mathrm{g})$ was purchased from Amersham Corp. (Arlington Heights, IL). ${ }^{125}$ I-labeled rat IGF-II was iodinated using the chloramine-T procedure (27). ${ }^{125}$ I-labeled human IGF-II was prepared using the lactoperoxidase procedure as described by Gowan et al. (28).

\section{Collection of conditioned media}

Mitogen-free N2E medium ( $30 \mathrm{ml}$ per $150-\mathrm{cm}^{2}$ flask) was incubated for $3 \mathrm{~d}$ with confluent $\left(\sim 2-5 \times 10^{5}\right.$ cells $\left./ \mathrm{cm}^{2}\right)$ SK-N-AS cells. The conditioned medium was centrifuged to remove cells and cellular debris. Aprotinin (4.88 trypsin inhibitor units/ml) (Sigma Chemical Co.) was added to the supernatant and it was stored at $-70^{\circ} \mathrm{C}$ until it was further purified.

\section{Purification of IGF-II from conditioned medium}

IGFs were partially purified from SK-N-AS-conditioned medium by gel filtration at acid $\mathrm{pH}$ to dissociate and resolve the IGFs from their binding proteins (29). In these experiments, $5 \mathrm{ml}$ of conditioned medium was lyophilized, resuspended in $1 \mathrm{ml}$ of $1 \mathrm{M}$ acetic acid, and fractionated on a Sephadex G-50 column $(128 \mathrm{ml} ; 1.5 \times 85 \mathrm{~cm})$ that had been equilibrated with $1 \mathrm{M}$ acetic acid at room temperature.

${ }^{125}$ I-labeled rat IGF-II $(50,000 \mathrm{cpm})$ was added to the sample to identify the elution position of IGF-II; $73 \%$ of the applied radioactivity was recovered.

To identify fractions that had IGF activity but did not contain IGF-binding proteins, $100-\mu \mathrm{l}$ aliquots of alternate column fractions were dried, resuspended in Dulbecco's phosphate-buffered saline (without $\mathrm{Ca}^{2+}, \mathrm{Mg}^{2+}$ ) containing $0.2 \%$ fatty acid-free bovine serum albumin (No. A7511, Sigma Chemical Co.). Fractions containing IGF-binding proteins were identified using the charcoal separation assay (29). ${ }^{125} \mathrm{I}$-labeled rat IGF-II $(20,000 \mathrm{cpm})$ was incubated with $50-\mu \mathrm{l}$ aliquots of the resuspended fractions in a final volume of $0.4 \mathrm{ml}$ for $16 \mathrm{~h}$ at $4^{\circ} \mathrm{C}$. Unbound tracer radioactivity was removed with activated charcoal ( $5 \%$ suspension in phosphate-buffered saline containing
$2 \%$ fatty acid-free bovine serum albumin). IGF tracer radioactivity that was complexed to binding proteins remained in the charcoal supernate and was quantitated in a $\gamma$-spectrometer (Beckman Instruments Inc., Palo Alto, CA).

Fractions containing IGFs were identified in a radioreceptor assay using solubilized rat placental membranes as described below (30). Fractions containing activity in the IGF-II receptor assay, coeluting with ${ }^{125}$ I-IGF-II, and lacking binding protein activity were pooled.

\section{Radioligand assays for IGFs}

IGF-II radioreceptor assay using solubilized rat placental membranes. Rat placental membranes were prepared and solubilized with Triton $\mathrm{X}-100$. Aliquots of solubilized membrane $(0.5 \mu \mathrm{l}$ per tube) were incubated with ${ }^{125}$ I-labeled rat IGF-II $(20,000 \mathrm{cpm})$ and $5 \mu$ l aliquots of resuspended column fractions in a final volume of $0.3 \mathrm{ml}$ for $18 \mathrm{~h}$ at $4^{\circ} \mathrm{C}(30)$. Unbound radioactivity was removed with activated charcoal as described above. Radioactivity bound to receptor remained in the charcoal supernatant and was quantitated. Recombinant IGF-I showed $<0.3 \%$ cross-reactivity (results not shown).

IGF-II radioimmunoassay. Increasing amounts of recombinant human IGF-II or fractionated SK-N-AS-conditioned medium were incubated $\left(4^{\circ} \mathrm{C}, 16 \mathrm{~h}\right)$ with rabbit antiserum to human IGF-II $(1: 4,000$ final dilution) and ${ }^{125}$ I-labeled human IGF-II $(13,000 \mathrm{cpm})$ in a final volume of borate-buffered saline, $\mathrm{pH} 8.5$, containing $5 \mathrm{mg} / \mathrm{ml}$ bovine serum albumin as previously described (29). Radioactivity bound to the antibody was collected using protein A-containing Staphylococcus aureus (Pansorbin, Calbiochem-Behring Corp., La Jolla, CA). Recombinant IGF-I exhibited $\sim 1 \%$ cross-reactivity in this assay (results not shown).

$I G F-I$ radioimmunoassay. The radioimmunoassay for IGF-I (2) was performed as previously described (29). $B / B_{0}=0.5$ was observed with $0.27 \mathrm{ng}$ per tube IGF-I.

\section{Ligand binding assays for IGF cell surface receptors}

Confluent SK-N-AS cells were suspended in Puck's saline containing 1 mM EDTA, pelleted, and resuspended in Hepes binding buffer $\mathrm{pH}$ 8.0) (27). Each assay tube received ${ }^{125}$ I-labeled human IGF-I or rat IGF-II $(20,000 \mathrm{cpm}) ; 1 \times 10^{6}$ cells; and the indicated concentrations of either recombinant IGF-I, rat IGF-II, porcine insulin (Eli Lilly Co.), $\alpha$-IR-3 IgG, or control IgG (MOPC-21) in a final volume of $0.5 \mathrm{ml}$. Cell-associated radioactivity was determined after incubation for $18 \mathrm{~h}$ at $0^{\circ} \mathrm{C}$ as previously described (27).

\section{Mitogenesis assays}

Cell multiplication. Exponentially growing SK-N-AS cells were plated into replicate $25-\mathrm{cm}^{2}$ tissue culture dishes at a density of $1 \times 10^{4}$ cells $/ \mathrm{cm}^{2}$ in the indicated media and fed every $4 \mathrm{~d}$. Cells were harvested in Puck's saline containing $1 \mathrm{mM}$ EDTA and counted with an electronic particle counter (Coulter Electronics, Inc., Hialeah, FL).

In some studies, cell number was assessed by a colorimetric assay using 3-(4,5-dimethylthiazol-2-yl)-2,5-diphenyltetrazolium bromide (MTT) (31-33). This assay measures the reduction by living cells of a tetrazolium salt, MTT (Sigma Chemical Co.), to a blue-colored formazan product. Cells were plated in 96-well culture dishes $\left(3.1 \times 10^{4}\right.$ cells $\left./ \mathrm{cm}^{2}\right)$ in $100-\mu \mathrm{l}$ of the indicated media. At the indicated times, MTT was added $(0.1 \mathrm{mg}$; final concentration $1 \mathrm{mg} / \mathrm{ml})$ and the incubation continued for $3 \mathrm{~h}$ at $37^{\circ} \mathrm{C}$. The precipitated formazan was solubilized with an equal volume of $n$-propanol containing $0.4 \mathrm{~N} \mathrm{HCl}$, and the absorbance determined at 570 and $690 \mathrm{~nm}$ using an ELISA reader. After correction for the nonspecific absorbance at $690 \mathrm{~nm}$, the absorbance at $570 \mathrm{~nm}$ was found to be linearly proportional to cell number over the range of cell concentrations examined in our experiments (data not shown). The cell number in each well was determined from a standard curve relating absorbance to cell number. Treated and untreated cells were examined microscopically and confirmed that $\alpha$-IR-3 treatment decreased cell number (results not shown).

$\left[{ }^{3} \mathrm{H}\right]$ Thymidine uptake. Exponentially growing SK-N-AS cells (1 $\times 10^{6}$ cells $/ 0.4 \mathrm{ml}$ ) were pretreated with $\alpha-\mathrm{IR}-3 \mathrm{IgG}$, control IgG (MOPC-21), or no IgG, and plated into 96 -well dishes $\left(5 \times 10^{3}\right.$ cells/ 
$0.1 \mathrm{ml}$ per well) with or without the appropriate antibody $(1 \mu \mathrm{g} / \mathrm{ml})$ and the indicated amounts of IGF-I or IGF-II. After incubation for $48 \mathrm{~h}$, $\left[{ }^{3} \mathrm{H}\right]$ thymidine $(1 \mu \mathrm{Ci})$ (New England Nuclear, Boston, MA) was added to each well and the incubation continued for an additional $24 \mathrm{~h}$. Cells were collected using a semiautomatic cell harvester and lysed hypotonically, and the macromolecules were collected on a glass fiber filter. Cellular uptake of $\left[{ }^{3} \mathrm{H}\right]$ thymidine was determined by liquid scintillation counting.

\section{Tissue and tumor samples}

Tissue samples were flash-frozen and stored in liquid nitrogen until RNA was extracted. Normal adult tissues were obtained from patients who died of unrelated disease. Fetal tissues were kindly provided by the Department of Pediatrics, Central Laboratory for Human Embryology, Seattle, WA. Pheochromocytomas were obtained at surgery from eight adult patients (aged 20-50 yr) and kindly provided by Dr. Harry R. Keiser, National Heart, Lung and Blood Institute and Dr. W. Marston Linehan, National Cancer Institute, Bethesda, MD. Five tumors were benign; three were malignant. Neuroblastomas were obtained from five children aged $11 \mathrm{mo}$ to $8.5 \mathrm{yr}$, and were kindly provided by Dr. Audrey E. Evans, Children's Hospital of Philadelphia, Philadelphia, PA, and Dr. Joseph Gootenburg of Georgetown University, Washington, DC. Of the four primary tumors, two were adrenal and two were from extra-adrenal abdominal sites. A lung metastasis also was examined from one of the patients (aged $2.5 \mathrm{yr}$ ), and a bone metastasis was examined from another (aged $8 \mathrm{yr}$ ). Three of the primary tumors were stage IV; one was stage II. Two tumors were examined before chemotherapy: two primary tumors and both metastatic lesions were obtained from patients who had received chemotherapy. Two additional neuroblastomas, primary tumors of the adrenal gland, stage III and stage IV, were examined prior to chemotherapy (results not presented).

\section{Northern blot analysis}

Total RNA was prepared from SK-N-AS cells or tissues by the method of Chirgwin et al. (34). Polyadenylated mRNA was prepared from SK-N-AS cellular RNA and from adult human liver tissue RNA using oligo-dT chromatography (35). Northern blot hybridization was performed as previously described (36). Blots were hybridized with nicktranslated plasmid probes containing cDNA inserts for IGF-I (777-bp insert in pKT218 [37], kindly provided by K. Gabbay, Baylor College of Medicine, Houston, TX), rat IGF-II (pr-IGF-II-1, 780-bp insert in pUC12 [38]), or the type I IGF receptor (pIGF-I-R.85 [39], 2.5-kb fragment in pUC13, kindly provided by A. Ullrich, Genentech, Inc., San Francisco, CA). The pr-IGF-II-1 insert is $87 \%$ homologous to human IGF-II over the first 273 nucleotides (corresponding to parts of coding exons 2 and 3 ). In some experiments, IGF-II mRNA was detected using a 31-bp synthetic DNA sequence specific for IGF-II corresponding to nucleotides 535-565 (13) that was end-labeled using [ ${ }^{32}$ P]dATP (New England Nuclear) and terminal deoxynucleotidyl transferase (Bethesda Research Laboratories) according to the manufacturer's recommendations. Northern blots were hybridized at $42^{\circ} \mathrm{C}$ (plasmid DNA) or $37^{\circ} \mathrm{C}$ (oligonucleotide) overnight ( $3 \times$ SSPE, $50 \%$ formamide, $10 \%$ dextran sulfate, $5 \times$ Denhardt's solution, $1 \%$ sodium dodecyl sulfate, $0.5 \mathrm{mg} / \mathrm{ml}$ salmon sperm DNA), and washed $(0.15 \times$ SSC, $0.5 \%$ sodium dodecyl sulfate, $65^{\circ} \mathrm{C}, 30 \mathrm{~min}$ for plasmid DNA; $1 \times$ SSC, $0.5 \%$ sodium dodecyl sulfate, $37^{\circ} \mathrm{C}, 30 \mathrm{~min}$ for oligonucleotide).

\section{Results}

$S K-N-A S$ cells grow in mitogen-free medium. The SK-N-AS human neuroblastoma cell line has been propagated continuously in mitogen-free medium for longer than $10 \mathrm{mo}$. Fig. 1 compares the growth of SK-N-AS cells after plating in the absence of added growth factors and in medium supplemented with insulin $(1 \mu \mathrm{g} / \mathrm{ml})$ or $10 \%$ fetal bovine serum. After a $2-\mathrm{d}$ lag, the cells grew in mitogen-free medium at a rapid rate for the next $8 \mathrm{~d}$ (doubling time $39 \mathrm{~h}$ ) that was indistinguishable

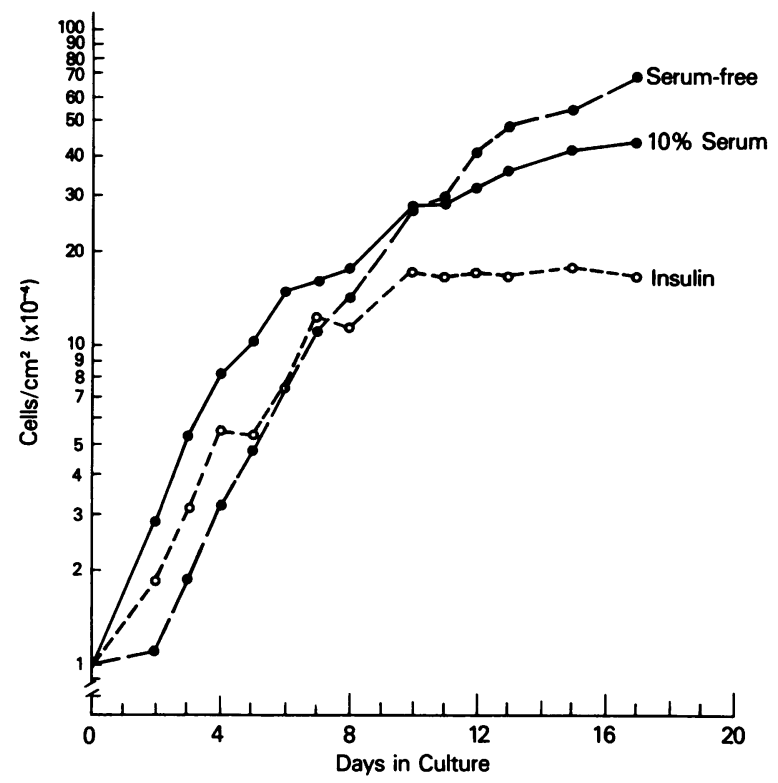

Figure 1. Growth of human neuroblastoma SK-N-AS cells in mitogen-free medium. Exponentially growing SK-N-AS cells were plated into replicate $25-\mathrm{cm}^{2}$ tissue culture dishes to a final cell density of 1 $\times 10^{4}$ cells $/ \mathrm{cm}^{2}$ containing N2E medium $(\bullet---\bullet)$, N2E medium supplemented with bovine insulin $(1 \mu \mathrm{g} / \mathrm{ml})$ (Sigma Chemical Co.) $(0--\infty)$, or basal medium supplemented with $10 \%$ fetal bovine

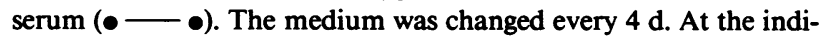
cated times, cells were harvested in saline/EDTA and counted using an electronic particle counter. Results shown are the mean of duplicate or triplicate evaluations that were each within $10 \%$ of the mean.

from that of cells grown in medium containing insulin or serum. The initial growth lag was observed consistently for cells grown in the absence of serum or insulin, but not in their presence. This suggested that rapid growth of SK-N-AS cells in mitogen-free medium required the endogenous synthesis of a growth factor. Since the growth lag was abolished by a supraphysiologic concentration of insulin, and since high concentrations of insulin frequently act as mitogens by cross-reacting with type I IGF receptors (40), we examined the possibility that the endogenous mitogen in SK-N-AS cells might be an IGF.

$S K-N-A S$ cells express $m R N A$ for IGF-II. RNA from SK-N-AS cells was examined by Northern blot hybridization analysis to determine if they expressed mRNA encoding IGF-I or IGF-II. Weak hybridization was observed using a cDNA probe for IGF-I and poly-A selected SK-N-AS mRNA (Fig. 2 $A$ ); no hybridization was detected in total RNA preparations from SK-N-AS cells (data not shown). Levels of IGF-I RNA in SK-N-AS cells were markedly lower than in normal adult liver. SK-N-AS cells shared a 1.8-kb IGF-I transcript with normal adult liver, but did not express the major 8.3-kb transcript, or the 4.4-, 3.8-, 1.1-, or $0.8-\mathrm{kb}$ transcripts found in adult liver (Fig. 2 A) (41). A 0.4-kb transcript seen in SK-N-AS cells was previously described for MCF-7 breast cancer cells and human placenta $(41,42)$. However, Yee et al. (43) failed to detect IGF-I RNA in MCF-7 and other breast cancer cell lines using a sensitive solution hybridization/RNAse protection assay, suggesting that the previously observed hybridization signal did not represent authentic IGF-I mRNA, but rather cross-hybridizing RNA species. 


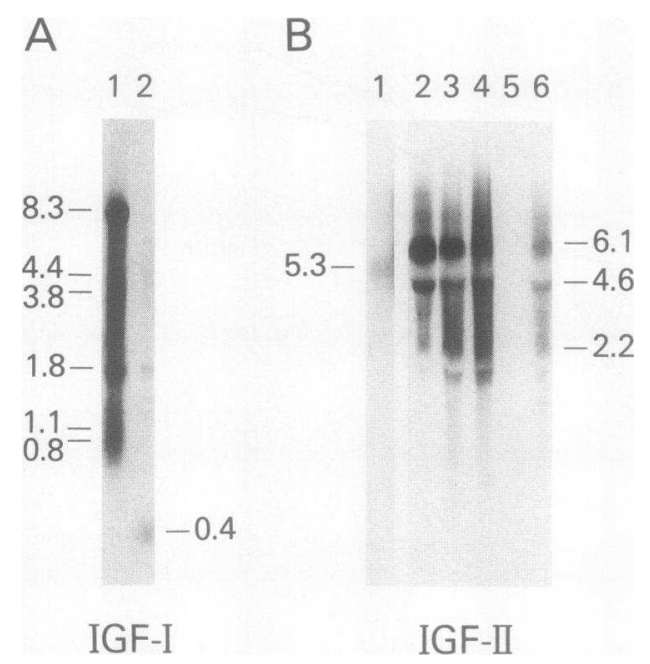

Figure 2. Expression of IGF-I and IGF-II mRNA by SK-N-AS cells. (A) Hybridization of ${ }^{32} \mathrm{P}$-labeled cDNA probe for human IGF-I to polyadenylated RNA (10 $\mu \mathrm{g} /$ lane) from normal adult human liver (lane 1 ) or SK-N-AS cells (lane 2). (B) Hybridization of ${ }^{32} \mathrm{P}$-labeled 31-bp deoxyoligonucleotide specific for IGF-II to total RNA (30 $\mu \mathrm{g} /$ lane) from the indicated sources. Lane 1 , normal adult liver; lane 2 , SK-N-AS; lanes 3 and 4, fetal liver, 110- and 87-d gestation, respectively; lane 5, adult kidney; lane 6, fetal kidney (87-d gestation). Transcript sizes (in kilobases) were estimated by comparison of their migration to that observed for $28 \mathrm{~S}$ and $18 \mathrm{~S}$ ribosomal RNAs. The autoradiogram shown in $B$ was prepared without an intensifying screen: the same Northern blot was exposed for $30 \mathrm{~h}$ (lanes 2-6), or for $4 \mathrm{~d}$ (lane 1). The apparent smear in some of the lanes has been observed previously for human IGF-II (10). We do not believe this results from the degradation of RNA, since sharp ribosomal RNA bands were clearly detected on ethidium bromide-stained gels and subsequent hybridization of these blots with other probes revealed sharp, discrete bands (not shown).

In contrast to IGF-I mRNA, high levels of IGF-II mRNA were readily detectable and quite abundant in total cellular RNA from SK-N-AS cells (Fig. 2 B, lane 2). IGF-II RNA levels in SK-N-AS cells were similar to those in fetal liver and kidney, and markedly greater than in adult liver and kidney. The sizes of the IGF-II mRNAs we detected, 6.1, 4.6, and $2.2 \mathrm{~kb}$, correspond to the sizes of mRNAs transcribed from the two promoters utilized in human fetal liver and other fetal and adult tissues and tumors $(12,14)$, but not to the 5.3-kb mRNA synthesized from a different promoter $(12,14)$ and only expressed in adult human liver (10-15) (Fig. $2 B$, lane 1 ).

$S K-N-A S$ cells synthesize IGF-II. To determine whether the abundant IGF-II RNA in SK-N-AS cells is translated into protein, conditioned medium was concentrated and gel-filtered on a Sephadex G-50 column at pH 2.3 to obtain an IGF pool uncontaminated by IGF-binding proteins (Fig. 3). Fractions 48-65 contained IGF activity, as recognized by the inhibition of ${ }^{125}$ I-IGF-II tracer binding to rat placental IGF-II receptors and coelution with a 7.5-kD ${ }^{125}$ I-IGF-II marker included in the gel filtration sample, and were well resolved from IGF binding proteins (fractions 31-40). Fractions in the IGF peak (fractions 48-65) were pooled and examined in a radioimmunoassay and a radioreceptor assay that are specific for IGF-II. Dilutions of the pooled IGF fractions inhibited ${ }^{125} \mathrm{I}$ IGF-II tracer binding to antibody (Fig. $3 B$ ) and receptor (Fig.
$3 C$ ) with a dose-response curve parallel to that observed with a recombinant human IGF-II standard. The concentration of IGF-II in SK-N-AS-conditioned medium was calculated to be $57 \pm 4 \mathrm{ng} / \mathrm{ml}(n=2)$ by radioimmunoassay and $54 \mathrm{ng} / \mathrm{ml}$ by radioreceptor assay, without correction for recovery. (Recovery of ${ }^{125} \mathrm{I}$-IGF-II added to the sample before gel filtration was $73 \%)$.

When a comparable IGF pool was assayed using an IGF-I radioimmunoassay (2), small degrees of inhibition were observed with larger volumes of conditioned media giving an inhibition curve that was nonparallel to the recombinant IGF-I standard (not shown). At most, the content of immunoreactive IGF-I in these samples was estimated as $<0.8 \mathrm{ng} / \mathrm{ml}$ at $B / B_{0}=0.8$, and $<0.3 \mathrm{ng} / \mathrm{ml}$ at $B / B_{0}=0.5$, although the nonparallelism of the dose-response curve argues against the apparent activity representing authentic IGF-I. Thus, SK-NAS cells synthesize and secrete appreciable amounts of IGF-II and little, if any, IGF-I.

$S K-N$-AS cells possess type I IGF receptors on their cell surface. IGF-II binds with high affinity to at least two structurally distinct receptors: the type I IGF receptor that has intrinsic tyrosine kinase activity and the IGF-II/mannose-6phosphate receptor, a multifunctional receptor that, in addition to binding IGF-II, also binds lysosomal enzymes containing a mannose-6-phosphate recognition marker (39, $40,44,45)$. The two receptors also differ in their binding specificity for IGF-I, IGF-II, and insulin, and in their recognition by anti-receptor antibodies (40). Only the type I IGF receptor has been shown conclusively to mediate the mitogenic activities of IGF-I and IGF-II (46-51).

In competitive binding experiments using ${ }^{125} \mathrm{I}-\mathrm{IGF}-\mathrm{I}$, we identified typical type I IGF receptors on the surface of SK-NAS cells (Fig. $4 \mathrm{~A}$ ). IGF-I tracer binding at $0^{\circ} \mathrm{C}$ was inhibited in a dose-dependent fashion by unlabeled IGF-I $\left(\mathrm{ED}_{50} 5.9 \pm 1.6\right.$ $\mathrm{ng} / \mathrm{ml}, n=4)$; rat IGF-II was four times less potent than IGF-I and insulin 600 times less potent than IGF-I $(n=3)$. A monoclonal antibody specific for type I IGF receptors, $\alpha$-IR-3 (25, 26), inhibited the binding of IGF-I tracer to SK-N-AS cells in a dose-dependent fashion, reaching a maximum of $80 \%$ inhibition. No inhibition was observed with an isotypic control immunoglobulin (Fig. $4 \mathrm{~A}$ ). Affinity cross-linking experiments confirmed that ${ }^{125}$ I-IGF-I bound specifically to a $130-\mathrm{kD}$ complex under reducing conditions, appropriate for the $\alpha$ subunit of the type I receptor (results not shown).

Binding of ${ }^{125} \mathrm{I}-\mathrm{IGF}-\mathrm{II}$ to SK-N-AS cells was $\sim 25 \%$ as much as that observed with ${ }^{125}$ I-IGF-I. The binding of IGF-II tracer was inhibited by IGF-I, IGF-II, and insulin with a similar affinity and order of potency as that observed with IGF-I tracer (Fig. $4 \mathrm{~B}$ ), a specificity characteristic of type I IGF receptors rather than IGF-II/mannose-6-phosphate receptors. Consistent with this interpretation, affinity cross-linking after binding ${ }^{125}$ I-IGF-II to SK-N-AS cells identified complexes of $130 \mathrm{kD}$ as well as $260 \mathrm{kD}$ (dimers of the $130-\mathrm{kD}$ subunit or IGF-II/mannose-6-phosphate receptors) under reducing conditions (not shown). In contrast to IGF-I tracer binding, the binding of IGF-II tracer was minimally inhibited by $\alpha$-IR-3 immunoglobulin. The properties of this binding site suggest that it represents a variant high-affinity binding site on the type I IGF receptor similar to that described in human placenta (52). Thus, the type I IGF receptor of SK-N-AS cells possesses both typical and variant high-affinity binding sites for IGF-I and IGF-II. 

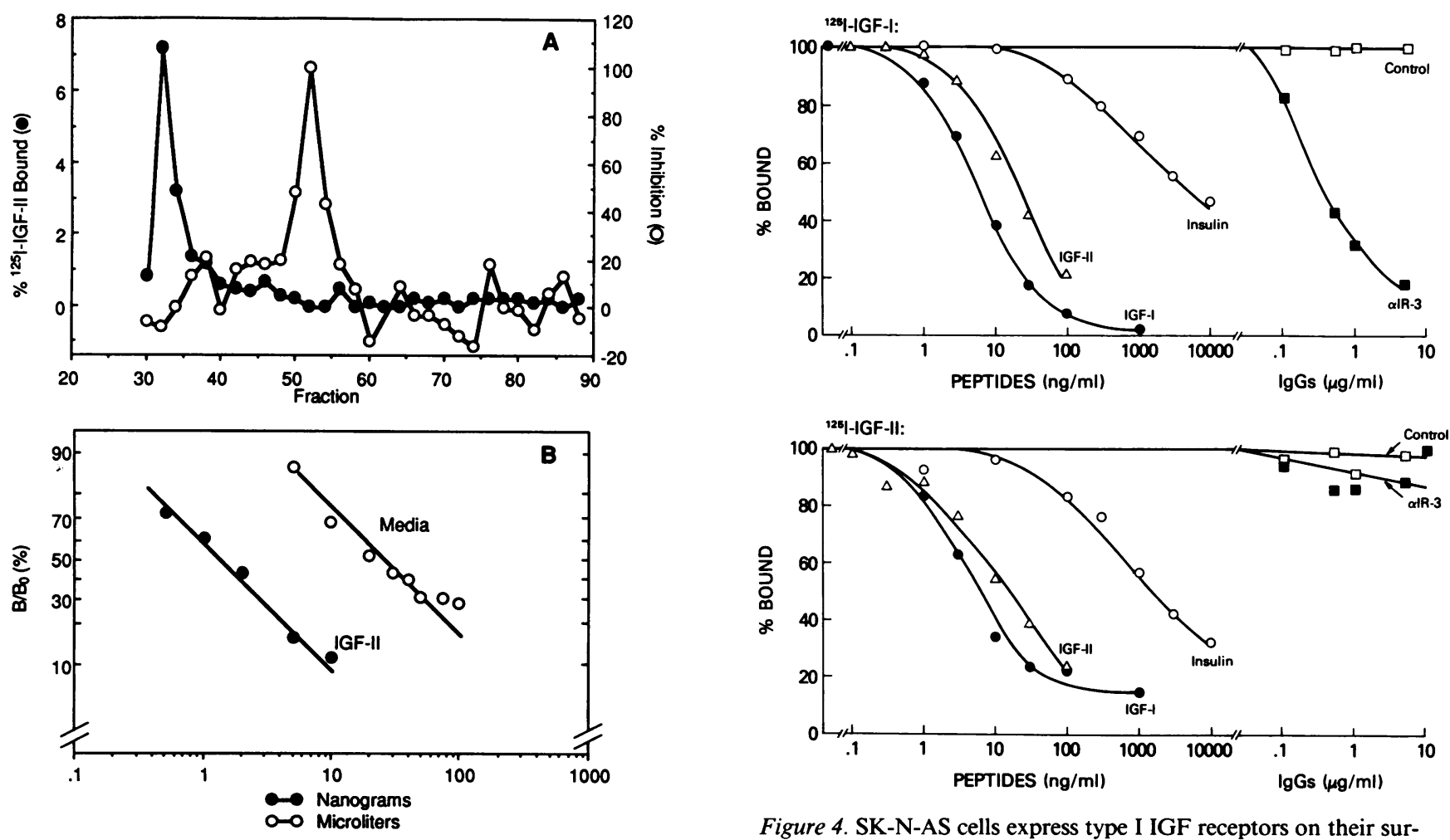

Figure 4. SK-N-AS cells express type I IGF receptors on their sur-

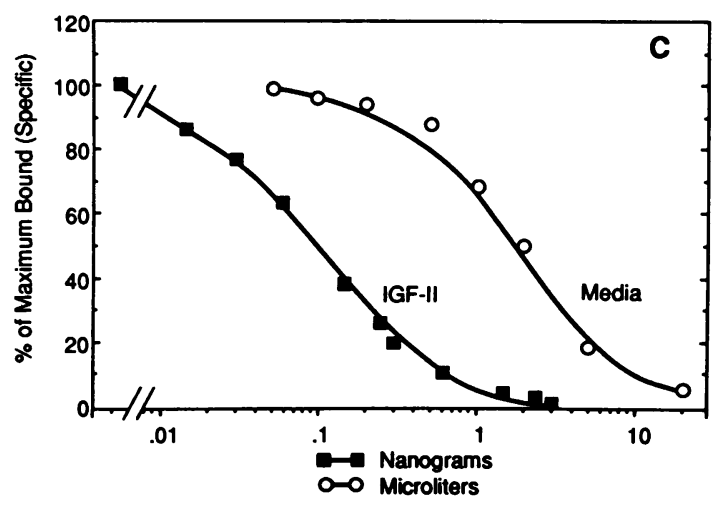

face. Suspended SK-N-AS cells were incubated with ${ }^{125}$ I-IGF-I (top) or ${ }^{125} \mathrm{I}$-IGF-II (bottom) in the presence of the indicated concentrations of unlabeled IGF-I $(\bullet)$, rat IGF-II $(\Delta)$, porcine insulin (Eli Lilly Co.; O), $\alpha$-IR-3 IgG (ø), or MOPC-21 IgG (ㅁ) as described in Methods. The percentage of maximum ${ }^{125}$ I-IGF bound $(23.4 \%$ of input radioactivity for ${ }^{125} \mathrm{I}$-IGF-I, $8.0 \%$ for ${ }^{125} \mathrm{I}$-IGF-II) is plotted against the concentration of added peptide $(\mathrm{ng} / \mathrm{ml})$ or immunoglobulin $(\mu \mathrm{g} / \mathrm{ml})$. Results of a representative experiment are shown.

Exogenous IGF-I and IGF-II stimulate $\left[{ }^{3} \mathrm{H}\right]$ thymidine uptake in $S K-N-A S$ cells. When increasing concentrations of IGF-I or IGF-II were added to sparsely seeded cultures of SK-N-AS cells for $48 \mathrm{~h}$, there was a dose-dependent increase in $\left[{ }^{3} \mathrm{H}\right]$ thymidine uptake from $48-72 \mathrm{~h}$ to nearly twice the basal level (Fig. 5). The concentration of IGF-I required for halfmaximal stimulation of $\left[{ }^{3} \mathrm{H}\right]$ thymidine uptake $(3.3 \pm 2.2$ Figure 3. Demonstration of IGF-II in SK-N-AS conditioned medium. $(A)$ Fractionation of IGF-II and IGF binding proteins by gel filtration (Sephadex G-50) at acid pH. Concentrated SK-N-AS medium was gel-filtered as described in Methods. Aliquots of column fractions were examined for IGF binding protein activity using a charcoal separation assay as described in Methods. The percentage of input ${ }^{125}$ I-labeled rat IGF-II bound to SK-N-AS binding proteins (•) is shown. IGF-II activity in aliquots of the indicated column fractions was determined as inhibition of ${ }^{125}$ I-IGF-II binding to solubilized IGF-II receptors from rat placental membranes (see Methods). The percentage of maximum inhibition of tracer binding by aliquots of each fraction is plotted (o). Total binding represents $48.6 \%$ of input radioactivity; binding was inhibited $26.9 \%$ by $5 \mu \mathrm{l}$ of fraction 52. Based on the calibration using ${ }^{125}$ I-labeled IGF-II (not shown) and the IGF-II radioreceptor assay, fractions 48-65 were identified as the IGF pool, combined and lyophilized. $(B)$ IGF-II radioimmunoassay of the IGF pool from fractionated SK-N-AS-conditioned medium. Increasing amounts of recombinant human IGF-II standard $(\bullet)$ or the IGF pool of gel-filtered SK-N-AS media from a column similar to that shown in $A(0)$, were incubated with rabbit antiserum to human IGF-II $(1: 4,000)$ and ${ }^{125}$ I-labeled human IGF-II $(20,000$ $\mathrm{cpm})$ as described in Methods. Maximum binding $\left(B_{0}\right)$ determined in the absence of added peptide or media was $30 \%$ of input radioactivity. $B / B_{0}(\%)$ is plotted on a logit-log scale for each concentration $\mathrm{ng} / \mathrm{ml}, n=4$ ) was similar to that which inhibited ${ }^{125} \mathrm{I}-\mathrm{IGF}-\mathrm{I}$ binding to SK-N-AS cells by $50 \%$ (Fig. $4 \mathrm{~A}$ ). IGF-II stimulated $\left[{ }^{3} \mathrm{H}\right]$ thymidine uptake in SK-N-AS cells with $90 \%$ the potency of IGF-I in one experiment (data not shown) and $40 \%$ the potency of IGF-I in the experiment presented in Fig. 5; insulin was $0.3 \pm 0.5 \%$ as potent as IGF-I $(n=3)$ (data not shown). A panel of other peptides including EGF, aFGF, bFGF, ECGF, PDGF, and TGF- $\beta_{1}$ at concentrations as high as $100 \mathrm{ng} / \mathrm{ml}$ or $\mathrm{G}-\mathrm{CSF}$ at $100 \mathrm{U} / \mathrm{ml}$ did not stimulate $\left[{ }^{3} \mathrm{H}\right]$ thymidine uptake in

of added peptide ( $\bullet, \mathrm{ng} /$ tube) or media $(0, \mu \mathrm{l} /$ tube). $(C)$ IGF-II radioreceptor assay of the IGF pool from fractionated SK-N-AS-conditioned medium. Increasing amounts of recombinant human IGF-II standard ( $(\mathbf{)})$ or of the same IGF pool of SK-N-AS media examined in $B(0)$ were incubated with ${ }^{125}$ I-labeled rat IGF-II and solubilized rat placental membranes as described in Methods. In the absence of added IGF-II or media, $41 \%$ of input radioactivity was bound $(31.6 \%$ specific). The percentage of maximum specific binding is plotted for each concentration of peptide ( $\mathrm{ng} /$ tube; $\boldsymbol{\varpi})$ or media ( $\mu \mathrm{l} /$ tube; $O$ ). 


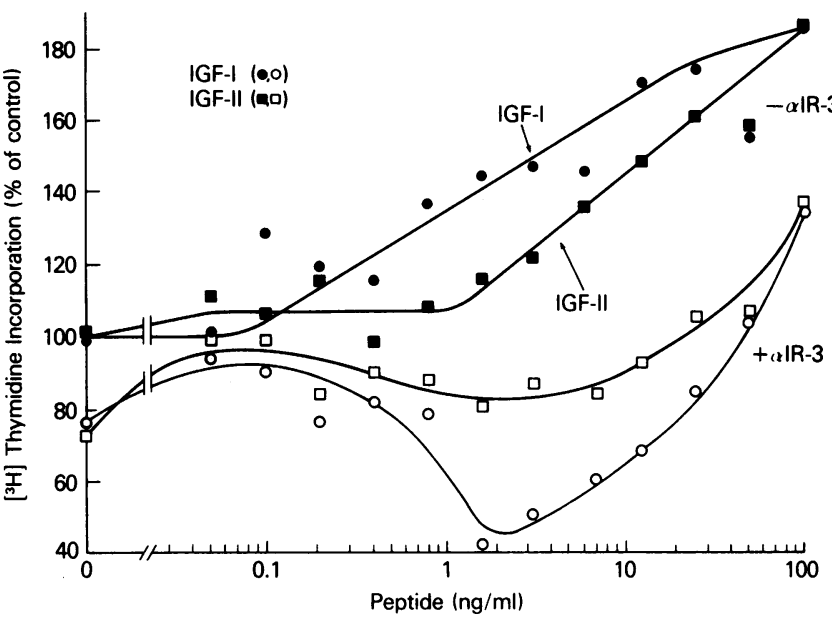

Figure 5. Exogenous IGF-I and IGF-II stimulate $\left[{ }^{3} \mathrm{H}\right]$ thymidine uptake by SK-N-AS cells via type I IGF receptors. Exponentially growing SK-N-AS cells were harvested and incubated at $4^{\circ} \mathrm{C}$ for $2 \mathrm{~h}$ in N2E medium with (open symbols), or without (closed symbols) $\alpha$-IR-3 IgG ( $2 \mu \mathrm{g} / \mathrm{ml})$ as described in Methods. After treatment, 5 $\times 10^{3}$ of the appropriately treated cells were plated into a 96-well plate containing N2E medium and Hepes binding buffer with (open symbols) or without (closed symbols) $\alpha$-IR-3 $(1 \mu \mathrm{g} / \mathrm{ml})$, and the indicated amount of human IGF-I (circles) or human IGF-II (squares). After $48 \mathrm{~h},\left[{ }^{3} \mathrm{H}\right]$ thymidine was added to each well, and the incubation continued for an additional $24 \mathrm{~h} .\left[{ }^{3} \mathrm{H}\right]$ Thymidine uptake was determined as described in Methods. The results are the mean of quadruplicate determinations that were within $10 \%$ of the mean. Thymidine uptake (percentage of control) is plotted against peptide concentration $(\mathrm{ng} / \mathrm{ml})$. Control cells treated with MOPC-21 IgG gave similar results to those obtained for untreated cells (data not shown).

SK-N-AS cells under similar experimental conditions (data not shown).

An anti-receptor monoclonal antibody to the type I IGF receptor inhibits the stimulation of $\left[{ }^{3} \mathrm{H}\right]$ thymidine uptake by exogenous IGF-I and IGF-II. We next sought to determine whether the stimulation of thymidine uptake in SK-N-AS cells by exogenous IGF-I or IGF-II was mediated through the type I IGF receptor. In these experiments, SK-N-AS cells that had been preincubated with $\alpha-\operatorname{IR}-3 \operatorname{IgG}(2 \mu \mathrm{g} / \mathrm{ml})$ or an irrelevant IgG (MOPC-21) were plated into medium containing IGF-I or IGF-II with $\alpha$-IR-3 IgG $(1 \mu \mathrm{g} / \mathrm{ml})$ or control IgG for $48 \mathrm{~h}$. $\left[{ }^{3} \mathrm{H}\right]$ Thymidine was added, and its uptake measured after $24 \mathrm{~h}$ (Fig. 5). Uptake in the absence of added peptides was inhibited $\sim 25 \%$ by $\alpha$-IR-3. The mitogenic effects of up to $25 \mathrm{ng} / \mathrm{ml}$ of IGF-I or IGF-II were completely inhibited by $\alpha$-IR-3. This inhibition was partially overcome by higher concentrations of growth factors. Curiously, $\left[{ }^{3} \mathrm{H}\right]$ thymidine uptake in the presence of $\alpha$-IR-3 and $2-20 \mathrm{ng} / \mathrm{ml}$ of IGF-I was lower than that observed with $\alpha$-IR-3 or the same concentrations of IGF-I added separately. This superinhibition was repeatedly observed and may reflect inhibition of endogenous growth stimulation through this receptor.

An anti-receptor monoclonal antibody inhibits the autocrine growth of $S K-N-A S$ cells. In the preceding experiment, we observed that $\alpha$-IR-3 inhibits $\left[{ }^{3} \mathrm{H}\right]$ thymidine uptake into SK-N-AS cells even in the absence of exogenously added IGFs (Fig. 5). In the experiment shown in Fig. 6, we evaluated the effect of this antibody on the proliferation of SK-N-AS cells.

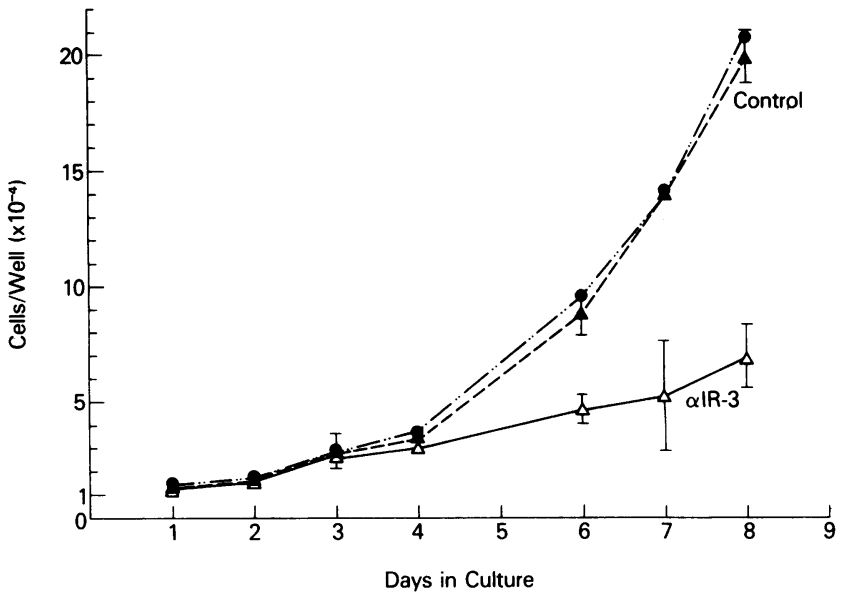

Figure 6. Anti-receptor antibody $\alpha$-IR-3 inhibits the growth of SK-N-AS cells. Exponentially growing SK-N-AS cells $\left(1 \times 10^{4}\right)$ were plated into wells of a 96-well tissue culture dish $\left(0.32-\mathrm{cm}^{2}, 3.1 \times 10^{4}\right.$ cells $\left./ \mathrm{cm}^{2}\right)$ containing control antibody MOPC-21 $(1 \mu \mathrm{g} / \mathrm{ml})(\Delta)$, $\alpha$-IR-3 antibody $(1 \mu \mathrm{g} / \mathrm{ml})(\Delta)$, or vehicle alone (Tris/HCl, $\mathrm{pH} 7.2)$ $(\bullet)$ in N2E medium ( $100 \mu \mathrm{l}$ final volume). Concentrated antibody (100 $\mathrm{ng}$ in $2.7 \mu \mathrm{l}$ ), or vehicle, was added to each well at $36 \mathrm{~h}$ after plating (final concentration of added antibody $1 \mu \mathrm{g} / \mathrm{ml}$ ). The cells were fed on day 6 with $50 \mu \mathrm{l}$ of medium containing antibody (1 $\mu \mathrm{g} / \mathrm{ml}$ ) or vehicle. Cell number was determined on the indicated days using the MTT assay as described in Methods. The data presented are from a representative experiment in which each point is the mean \pm SD of triplicate or quadruplicate determinations. For clarity, the error bars were omitted from the data points representing vehicle alone. SD for these data points was $<10 \%$.

Cell number was determined using a colorimetric assay that measures the reduction of the tetrazolium salt MTT (31-33); cell number was linearly proportional to absorbance over the range of cell concentrations tested. SK-N-AS cells were seeded into medium supplemented with either $\alpha$-IR-3 IgG, control IgG (MOPC-21) or vehicle alone, and re-treated with antibody at $36 \mathrm{~h}$ and $6 \mathrm{~d}$ after plating. During the first $4 \mathrm{~d}$ of incubation, $\alpha$-IR-3-treated cells grew at a rate similar to that of control cells. Subsequently, the rate of growth of the $\alpha$-IR-3-treated cells declined, relative to that of the control cultures. After $8 \mathrm{~d}$, the increase in cell number in cultures treated with $\alpha$-IR-3 was $\sim 30 \%$ of that in control cultures. (Similar inhibition was observed in cultures that received antibody at $12,24,36$, and 48 $\mathrm{h}$, or at 36 and $72 \mathrm{~h}$, in addition to the time of plating and day 6. Less inhibition was observed when the antibody was added only at the time of plating and at day 6 , or at these two times and at 24 and $48 \mathrm{~h}$, suggesting that the presence of fresh antibody at $36 \mathrm{~h}$, before the second cycle of DNA synthesis, may be critical). The inhibition of growth of SK-N-AS cells by $\alpha$-IR-3 does not appear to be due to nonspecific toxicity as $\alpha$-IR-3 had no effect on several other tumor cell lines tested in our laboratory (data not shown). These results suggest that the growth of SK-N-AS cells is mediated by endogenously produced growth factors, most probably IGF-II, acting through a type I IGF receptor.

IGF-II $m R N A$ and type I IGF receptor $m R N A$ are expressed in neuroblastoma and pheochromocytoma tumors and normal adrenal medulla. Since IGF-II appeared to be involved in the autocrine growth of the SK-N-AS neuroblastoma tumor cell line, we surveyed neuroblastomas and pheochromocy- 
tomas, tumors of mature adrenal medullary cells that are distinct from neuroblastoma and typically occur during adulthood (53), for the expression of IGF-II mRNA. Using Northern blot hybridization analysis of total RNA, we found that IGF-II mRNA was expressed in two of six neuroblastomas (Fig. 7 A). ${ }^{2}$ Two additional neuroblastoma tumors also did not express detectable IGF-II mRNA (data not shown). Similarly, IGF-II gene expression was reported previously in one of four neuroblastomas $(10,11,16)$. In contrast, IGF-II mRNA was detected in eight of eight pheochromocytoma tissues (Fig. 7 B). Haselbacher et al. (54) observed slightly increased IGF-II mRNA and 20-fold higher IGF-II protein levels compared with adult adrenal medulla in three of three pheochromocytomas. IGF-II mRNA was also detected in adult adrenal medulla, but not in adrenal cortex (Fig. $7 \mathrm{~B}$, lanes 10 and 11 , respectively).

Adrenal medullary tumors also express the gene for the type I IGF receptor. We detected type I IGF receptor mRNA in six of six neuroblastomas and seven of the eight pheochromocytoma tumors examined for the presence of IGF-II mRNA (Fig. 7, $C$ and $D$, respectively). Type I receptor mRNA also was detected in adrenal medulla, and to a lesser extent, in adrenal cortex (Fig. $7 \mathrm{D}$, lanes 10 and 11 , respectively). These findings suggest that the IGF-II-mediated autonomous growth stimulation seen in neuroblastoma-derived SK-N-AS cells might contribute to the growth of some adrenal medullary tumors in vivo.

\section{Discussion}

IGF-II mRNA is expressed at high levels in a wide range of human tumors (11). These include Wilms' tumor $(10,16,54)$, rhabdomyosarcoma $(10,11)$, liposarcoma $(55), 40 \%$ of colon carcinomas (55), leiomyomas/leiomyosarcomas (41), breast carcinomas (56), and $20 \%$ of hepatic carcinomas (57). IGF-II RNA also is increased in rat medullary thyroid carcinomas (58) and hepatocellular carcinomas $(59,60)$, and in woodchuck hepatocellular carcinomas that develop after chronic infection with woodchuck hepatitis virus (61). These studies do not address the question of whether the expression of IGFII mRNA is an epiphenomenon or consequence of tumorigenesis, or whether IGF-II is involved in the initiation or propagation of the tumors. For example, in only a few instances has tumor expression of IGF-II protein been reported. Immunoreactive IGF-II was demonstrated in tumor extracts in three pheochromocytomas (54) and one leiomyosarcoma (62). In the latter case, and in two preliminary reports $(63,64)$, expression of IGF-II protein was suggested by the occurrence of clinical hypoglycemia, presumably resulting from the interaction of overproduced IGF-II with insulin receptors. In general, it has not been demonstrated that these tumors possess type I IGF receptors, the receptors that are thought to mediate the mitogenic effects of IGF-I and IGF-II, or that blockade of these receptors impairs cell multiplication. In the present study, we demonstrate that RNAs encoding IGF-II and the type I IGF receptor are expressed in two tumors of the adrenal medulla, neuroblastoma and pheochromocytoma, and in a neuroblas-

2. It is perhaps noteworthy that the SK-N-AS cell line and the two neuroblastomas expressing IGF-II were obtained from metastatic lesions. toma cell line (SK-N-AS). We present evidence strongly suggesting that physiologically relevant levels of IGF-II protein are synthesized and secreted by SK-N-AS cells, and that, by interacting with the type I IGF receptor, it contributes to the autocrine growth of these cells. This mechanism may be important for the growth of both normal adrenal medulla tissue and some adrenal medullary tumors.

SK-N-AS cells express IGF-II mRNA at high levels. The sizes of the observed mRNAs, 6.1 and $4.6 \mathrm{~kb}$, suggest that they arise from the two promoters that are expressed in fetal liver (and in other fetal and adult tissues), rather than from the weak promoter that only is utilized in adult liver $(12,14)$. A 2.2-kb mRNA also was observed that is thought to arise from the same promoter as the 6.1-kb RNA, but utilizes a different poly A addition site (14).

SK-N-AS cells synthesize and secrete sufficient quantities of IGF-II protein to stimulate mitogenesis in these cells. An IGF pool was prepared by acid gel filtration of conditioned media that was demonstrated to be free of any contamination by IGF binding proteins which also are synthesized and secreted by SK-N-AS cells. The pooled IGF fractions were assayed in a radioreceptor assay and a radioimmunoassay that are specific for IGF-II and have negligible cross-reactivity with IGF-I. The dose-response curves obtained with an IGF pool from SK-N-AS-conditioned medium were parallel to those of a recombinant IGF-II standard, consistent with the reactive material being authentic IGF-II. Its coelution with a radiolabeled ${ }^{125}$ I-IGF-II marker on the gel filtration column suggests that the E-domain propeptide had been removed from the 17.6-kD pro-IGF-II precursor $(65){ }^{3}$

SK-N-AS cells express little, if any, IGF-I mRNA. A weak hybridization signal was detected by Northern blot analysis of poly A-enriched, but not total, RNA. However, the atypical size of these RNAs suggested that they may represent cross-hybridizing RNAs rather than authentic IGF-I mRNA (43). Examination of the IGF pool from SK-N-AS conditioned media in a specific radioimmunoassay did not identify authentic IGF-I protein. Minor inhibition was observed at high protein concentrations, but the dose-response curve was not parallel to that of the recombinant IGF-I standard, suggesting that the cross-reacting material was not IGF-I.

SK-N-AS cells possess type I IGF receptors on their surface, based on the specificity of inhibition of ${ }^{125}$ I-IGF-I binding by unlabeled IGF-I, IGF-II, and insulin, the presence of a $130-\mathrm{kD}$ binding subunit, and the inhibition of ${ }^{125} \mathrm{I}-\mathrm{IGF}-\mathrm{I}$ binding by the $\alpha$-IR-3 monoclonal antibody. The type I IGF receptor has been shown to mediate the mitogenic effects of both IGF-I $(46,47)$ and IGF-II $(48,49)$. This also appears to be the case for SK-N-AS cells. DNA synthesis is stimulated most potently by IGF-I, by slightly higher concentrations of IGF-II, and by high concentrations of insulin. This profile mirrors the relative affinities of the three peptides for binding to the type I IGF receptor (40). Moreover, stimulation of DNA synthesis by exogenous IGF-I and IGF-II (Fig. 5) and insulin (not shown) was inhibited by $\alpha$-IR-3 IgG, but not by an isotypic control IgG.

3. Although the major peak of receptor reactivity corresponds to 7.5kD IGF-II, we have not excluded the presence of small amounts of partially processed or unprocessed pro-IGF-II containing all or part of the E-domain propeptide. 
A
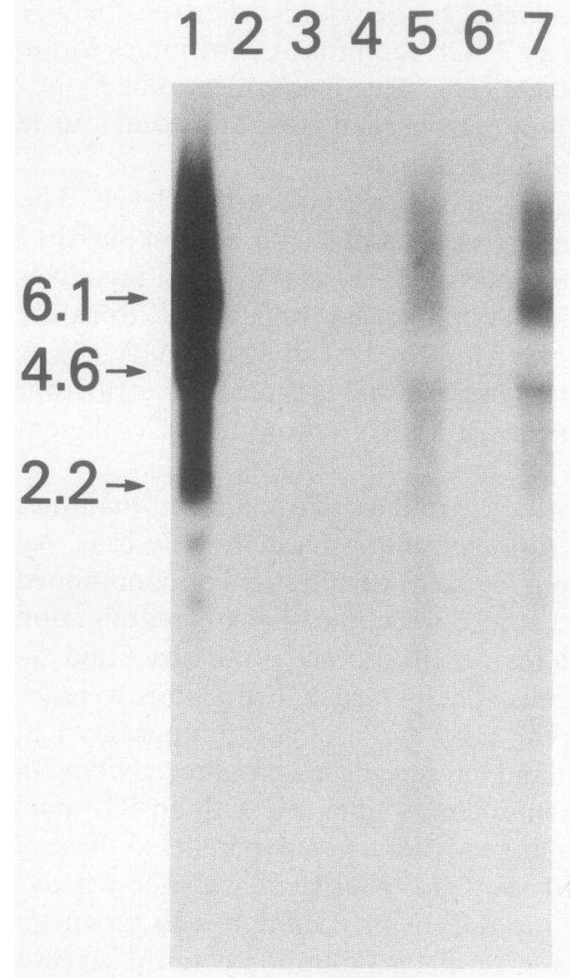

C
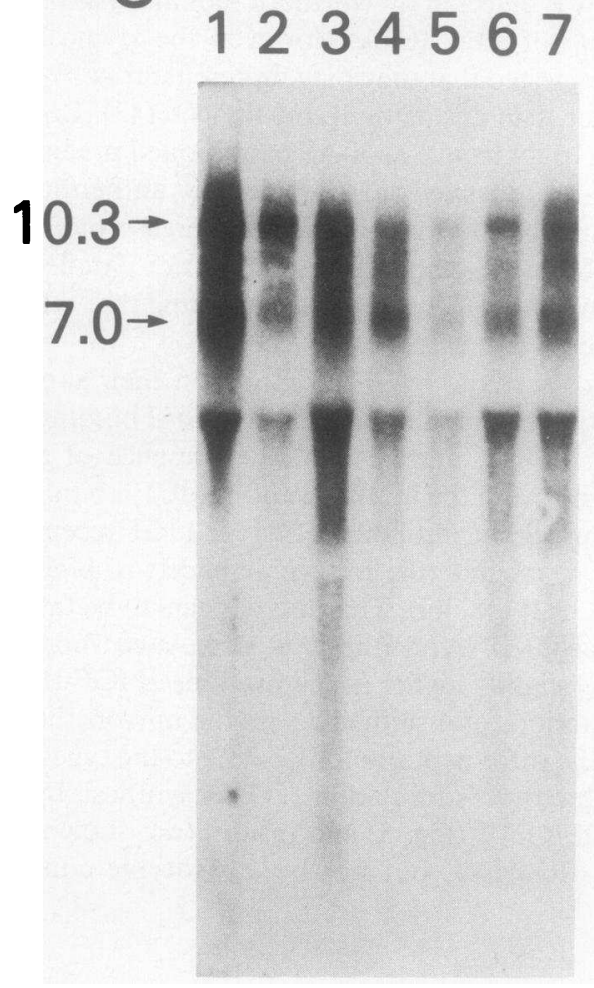

\section{1}
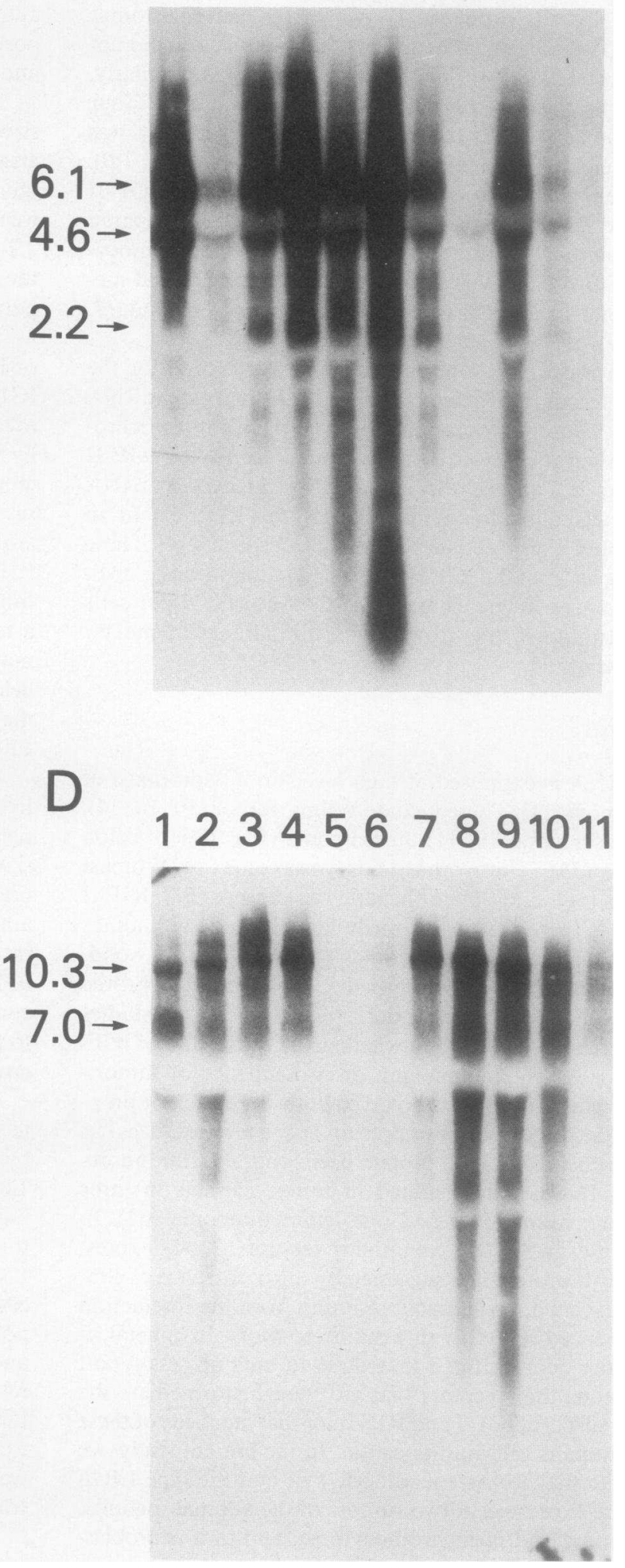

Figure 7. Expression of IGF-II and type I IGF receptor genes in the human adrenal gland and in tumors of the adrenal medulla. Total RNA (30 $\mu \mathrm{g}$ per lane, except for $8 \mu \mathrm{g}$ in lane 10 of panels $B$ and $D$ ) was examined by Northern blot analysis for IGF-II gene expression $(A$ and $B$ ), and for IGF-I receptor gene expression $(C$ and $D)$. ( $A$ and $C)$ Replicate blots of RNA extracted from neuroblastoma tumor tissues from different patients (lanes 2-6) and from SK-N-AS cells (lane 1). RNA in lanes 2-4 and lanes 6 are from primary tumors. RNA in lane 5 is from a 
IGF-II tracer appears to bind to a variant binding site on the type I IGF receptor on SK-N-AS cells: it is similar in size and peptide binding specificity, but is not inhibited by $\alpha-$ IR-3. Similar binding sites have been reported in other systems, for example, human placental membranes (52). Whether the variant site is functional has not been determined. However, in SK-N-AS cells, $\alpha$-IR-3 nearly completely inhibits the stimulation of DNA synthesis by exogenous IGF-I and IGF-II, as well as autonomous cell multiplication, suggesting that these effects are mediated predominantly by the classic IGF binding site on the type I receptor.

We have observed little, if any, IGF-II tracer binding to cell-surface IGF-II/mannose-6-phosphate receptors. A 260-kD complex was seen with both IGF-I and IGF-II tracers in addition to the $130-\mathrm{kD}$ complex after affinity cross-linking and electrophoresis under reducing conditions. This might represent an IGF-II receptor, or a dimer of the $130-\mathrm{kD}$ binding subunit of the type I IGF receptor. Even though IGF-II receptors have a high affinity for IGF-II, it is unlikely that they mediate the endogenous growth of SK-N-AS cells. Although IGF-II may direct the subcellular localization of lysosomal enzymes by decreasing their binding to this receptor (66), there is no conclusive evidence that IGF-II exerts its mitogenic effects through this receptor $(40,45,48-51)$. In addition, since exogenous and autonomous mitogenesis in SK-N-AS cells are inhibited by $\alpha$-IR-3, an antibody that does not recognize the IGF-II receptor, these effects cannot be mediated by the IGF-II receptor.

A monoclonal antibody antagonist of the type I IGF receptor, $\alpha$-IR-3, inhibited the autonomous growth of SK-N-AS cells. First, in the absence of added peptide, $\left[{ }^{3} \mathrm{H}\right]$ thymidine uptake was inhibited $\sim 25 \%$ by $\alpha$-IR-3. A comparable inhibition of growth was observed in four small cell lung cancer cell lines that are thought to exhibit autocrine growth stimulation by IGF-I (32). Second, in the presence of low concentrations of added IGF-I, $\alpha$-IR-3 inhibited thymidine uptake below levels seen in untreated control cells. A similar response was observed for IGF-I stimulated cell multiplication in one of four small cell lung cancer cell lines (32). Although the mechanism of this inhibition is unclear, it suggests that under some circumstances (namely, low concentrations of IGF-I), $\alpha$-IR-3 can profoundly inhibit autonomous DNA synthesis. Finally, we demonstrated directly that $\alpha$-IR-3 IgG, but not control IgG, nearly completely inhibited the autonomous multiplication of SK-N-AS cells. The most likely explanation of this result is that the endogenous growth factor, IGF-II, acts through the type I IGF receptor to stimulate DNA synthesis and cell multiplication in SK-N-AS cells. Whether this represents autocrine stimulation by IGF-II that is secreted by SK-N-AS cells and taken up by type I IGF receptors on the cell surface, or internal direct activation of intracellular type $I$ receptors by IGF-II as described for PDGF receptors (67) is not known.

Thus, we have demonstrated that SK-N-AS cells derived from a human neuroblastoma replicate autonomously, at least in part, because of autocrine stimulation by IGF-II. Since some neuroblastomas and all pheochromocytomas synthesize substantial amounts of IGF-II mRNA, and since virtually all of these tumors express mRNA for the type I IGF receptor that mediates the autocrine growth stimulation by IGF-II, we propose that a similar autocrine stimulation by IGF-II may contribute to the growth of some tumors of the adrenal medulla.

Endogenously produced IGF-I and IGF-II are thought to participate in the growth of normal cells. Monoclonal antibodies directed against IGF-I (but cross-reacting with IGF-II) inhibited PDGF-stimulated growth of cultured human fibroblasts and porcine smooth muscle cells (attributed to IGF-I; 68) and thyrotropin-stimulated DNA synthesis in the FRTL5 rat thyroid cell line (attributed to IGF-II; 69). Yee et al. (56) reported that IGF-II mRNA expression in normal breast tissue was equal to or greater than that in breast carcinoma tissue from the same patient, suggesting that IGF-II may be produced by stromal cells rather than the tumor itself. The autocrine growth stimulation by IGF-II that we have observed in SK-N-AS cells also may be operative in normal adrenal medulla. IGF-II mRNA is expressed in adrenal medulla, as in other normal adult tissues $(10,11,70)$, and normal adrenal medulla also expresses RNA encoding the type I IGF receptor. Thus, the proliferation of adrenal medullary tumors may result from the pathologically altered expression of a normal cellular growth regulatory pathway.

\section{Acknowledgments}

We would like to thank Carly Rubinow for technical assistance, Ronnie Goldberg for secretarial assistance, Robert Dickson for helpful discussions, and S. Peter Nissley for critical reading of the manuscript.

Osama M. El-Badry is a recipient of a National Research Council(National Institutes of Health) Research Associateship.

\section{References}

1. Humbel, R. E. 1984. Insulin-like growth factors, somatomedins, and multiplication stimulating activity: chemistry. In Hormonal Proteins and Peptides. C. H. Li, editor. Academic Press, Inc., New York. 57-79.

2. Furlanetto, R. W., L. E. Underwood, J. J. Van Wyk, and A. J. D'Ercole. 1977. Estimation of somatomedin-C levels in normals and patients with pituitary disease by radioimmunoassay. J. Clin. Invest. 60:648-657.

3. Schoenle, E., J. Zapf, R. E. Humbel, and E. R. Froesch. 1982. Insulin-like growth factor I stimulates growth in hypophysectomized rats. Nature (Lond.). 296:252-253.

4. Clemmons, D. R., and J. J. Van Wyk. 1984. Factors controlling blood concentration of somatomedin C. Clin. Endocrinol. Metab. 13:113-143.

5. Daughaday, W. H., K. Hall, W. D. Salmon, Jr., J. L. Van den Brande, and J. J. Van Wyk. 1987. On the nomenclature of the somatomedins and insulin-like growth factors. Endocrinology. 121:19111912.

6. Moses, A. C., S. P. Nissley, P. A. Short, M. M. Rechler, R. M. White, A. B. Knight, and O. Z. Higa. 1980. Increased levels of multiplication-stimulating activity, and insulin-like growth factor, in fetal rat serum. Proc. Natl. Acad. Sci. USA. 77:3649-3653.

7. Adams, S. O., S. P. Nissley, S. Handwerger, and M. M. Rechler.

bone metastasis, and RNA in lane 7 is from a lung metastasis from the same patient as lane 6. $(B$ and $D)$ Sequential hybridization to the same blot of RNA from pheochromocytomas and normal adult adrenal tissues: lane 1, SK-N-AS; lanes 2-9, pheochromocytomas from different patients; lane 10, adrenal medulla; lane 11, adrenal cortex. Transcript sizes were estimated by comparison of their migration to that observed for $28 \mathrm{~S}$ and $18 \mathrm{~S}$ ribosomal RNAs. 
1983. Developmental patterns of insulin-like growth factor-I and -II synthesis and regulation in rat fibroblasts. Nature (Lond.). 302:150153.

8. Brown, A. L., E. E. Graham, S. P. Nissley, D. J. Hill, A. J. Strain, and M. M. Rechler. 1986. Developmental regulation of insulin-like growth factor II mRNA in different rat tissues. J. Biol. Chem. 261:13144-13150.

9. Soares, M. B., A. Turken, D. Ishii, L. Mills, V. Episkopou, S. Cotter, S. Zeitlin, and A. Efstratiadis. 1986. Rat insulin-like growth factor II gene: a single gene with two promotors expressing a multitranscript family. J. Mol. Biol. 192:737-752.

10. Scott, J., J. Cowell, M. E. Robertson, L. M. Priestley, R. Wadey, B. Hopkins, J. Pritchard, G. I. Bell, L. B. Rall, C. F. Graham, and T. J. Knott. 1985. Insulin-like growth factor-II gene expression in Wilms' tumor and embryonic tissues. Nature (Lond.). 317:260-262.

11. Gray, A., A. W. Tam, T. J. Dull, J. Hayflick, J. Pintar, W. K. Cavenee, A. Koufos, and A. Ullrich. 1987. Tissue-specific and developmentally regulated transcription of the insulin-like growth factor 2 gene. DNA (NY). 6:283-295.

12. de Pagter-Holthuizen, P., M. Jansen, F. M. A. van Schaik, R. van der Kammen, C. Oosterwijk, J. L. Van den Brande, and J. S. Sussenbach. 1987. The human insulin-like growth factor II gene contains two development-specific promoters. FEBS (Fed. Eur. Biochem. Soc.) Lett. 214:259-264.

13. Han, V. K. M., A. J. D'Ercole, and P. K. Lund. 1987. Cellular localization of somatomedin (insulin-like growth factor) messenger RNA in the human fetus. Science (Wash. DC). 236:193-197.

14. de Pagter-Holthuizen, P., M. Jansen, R. A. van der Kammen, F. M. A. van Schaik, and J. S. Sussenbach. 1988. Differential expression of the human insulin-like growth factor II gene. Characterization of the IGF-II mRNAs and an mRNA encoding a putative IGF-II associated protein. Biochim. Biophys. Acta. 950:282-295.

15. Han, V. K., P. K. Lund, D. C. Lee, and A. J. D'Ercole. 1988. Expression of somatomedin/insulin-like growth factor messenger ribonucleic acids in the human fetus: identification, characterization, and tissue distribution. Clin. Endocrinol. Metab. 66:422-429.

16. Reeve, A. E., M. R. Eccles, R. J. Wilkins, G. I. Bell, and L. J. Millow. 1985. Expression of insulin-like growth factor-II transcripts in Wilms' tumour. Nature (Lond.). 317:258-260.

17. Israel, M. A. 1986. The evolution of clinical molecular genetics: neuroblastoma as a model tumor. Am. J. Pediatr. Hematol. Oncol. 8:163-172.

18. Pizzo, P. A., J. S. Miser, J. R. Cassady, and R. M. Filler. 1985. Solid tumors of childhood. In Cancer: Principles and Practice of Oncology 2. V. T. DeVita, Jr., S. Hellman, and S. A. Rosenberg, editors. J. B. Lippincott Co., Philadelphia. 1511-1574.

19. Helson, L., B. Member, and C. Helson. 1984. Importance of clinical exposure on verapamil enhancement of adriamycin-vincristine cytotoxicity in human neuroblastoma. Cancer Drug Delivery. 1:303-305.

20. Sugimotto, T., E. Tatsumi, J. T. Kemshead, and L. Helson. 1984. Determination of cell surface membrane antigens common to both human neuroblastoma and leukemia-lymphoma cell lines by a panel of 38 monoclonal antibodies. J. Natl. Cancer Inst. 73:51-57.

21. Sugimotto, T., T. Sawada, S. Arakawa, T. Matsumura, I. Sakamoto, Y. Takeuchi, C. P. Reynolds, J. T. Kemshead, and L. Helson. 1985. Possible differential diagnosis of neuroblastoma from rhabdomyosarcoma and Ewing's sarcoma by using a panel of monoclonal antibodies. Jpn. J. Cancer Res. 76:301-307.

22. Bottenstein, J. E. 1980. Serum-free culture of neuroblastoma cells. In Advances in Neuroblastoma Research. A. E. Evans, editor. Prog. Cancer Res. Ther. 12:161-170.

23. Bottenstein, J. E. 1985. Growth and differentiation of neural cells in defined media. In Cell Culture in the Neurosciences. J. E. Bottenstein, and G. Sato, editors. Curr. Top. Neurobiol. 6:3-43.

24. Greenstein, L. A., L. A. Gaynes, J. A. Romanus, L. Lee, M. M.
Rechler, and S. P. Nissley. 1986. Purification of rat insulin-like growth factor II. In Peptide Growth Factors. D. Barnes, and D. A. Sirbasku, editors. Methods Enzymol. 146:259-269.

25. Kull, F. C., S. Jacobs, Y.-F. Su, M. E. Svoboda, J. J. Van Wyk, and P. Cuatrecasas. 1983. Monoclonal antibodies to receptors for insulin and somatomedin-C. J. Biol. Chem. 258:6561-6566.

26. Rohlik, Q. T., D. Adams, F. C. Kull, Jr., and S. Jacobs. 1987. An antibody to the receptor for insulin-like growth factor I inhibits the growth of MCF-7 cells in tissue culture. Biochem. Biophys. Res. Commun. 149:276-281.

27. Van Obberghen-Schilling, E. E., M. M. Rechler, J. A. Romanus, A. B. Knight, S. P. Nissley, and R. E. Humbel. 1981. Receptors for insulin-like growth factor I are defective in fibroblasts cultured from a patient with leprechaunism. J. Clin. Invest. 68:1356-1365.

28. Gowan, L. K., B. Hampton, D. J. Hill, R. J. Schlueter, and J. F. Perdue. 1987. Purification and characterization of a unique high molecular weight form of insulin-like growth factor II. Endocrinology. 121:449-458.

29. Romanus, J. A., A. Rabinovitch, and M. M. Rechler. 1985. Neonatal rat islet cell cultures synthesize insulin-like growth factor I. Diabetes. 34:696-702.

30. Kiess, W., G. D. Blickenstaff, M. M. Sklar, C. L. Thomas, S. P. Nissley, and G. G. Sahagian. 1988. Biochemical evidence that the type II insulin-like growth factor receptor is identical to the cation-independent mannose 6-phosphate receptor. J. Biol. Chem. 263:9339-9344.

31. Denizot, F., and R. Lang. 1986. Rapid colorimetric assay for cell growth and survival: modifications to the tetrazolium dye procedure giving improved sensitivity and reliability. J. Immunol. Methods. 89:271-277.

32. Nakanishi, Y., J. L. Mulshine, P. G. Kasprzyk, R. B. Natale, R. Maneckjee, I. Avis, A. M. Treston, A. F. Gazdar, J. D. Minna, and F. Cuttitta. 1988. Insulin-like growth factor-I can mediate autocrine proliferation of human small cell lung cancer cell lines in vitro. J. Clin. Invest. 82:354-359.

33. Nakanishi, Y., F. Cuttitta, P. G. Kasprzyk, I. Avis, S. M. Steinberg, A. F. Gazdar, and J. L. Mulshine. 1988. Growth factor effects on small cell lung cancer cells using a colorimetric assay: Can a transferrin-like factor mediate autocrine growth? Exp. Cell Biol. 56:74-85.

34. Chirgwin, J. M., A. E. Przybyla, R. J. MacDonald, and W. J. Rutter. 1979. Isolation of biologically active ribonucleic acid from sources enriched in ribonuclease. Biochemistry. 18:5294-5299.

35. Aviv, H., and P. Leder. 1972. Purification of biologically active globin messenger RNA by chromatography on oligothymidylic acidcellulose. Proc. Natl. Acad. Sci. USA. 69:1408-1412.

36. Thiele, C. J., C. P. Reynolds, and M. A. Israel. 1985. Decreased expression of $\mathrm{N}$-myc precedes retinoic acid-induced morphological differentiation of human neuroblastoma. Nature (Lond.). 313:404406.

37. Jansen, M., F. M. A. van Schaik, A. T. Ricker, B. Bullock, P. E. Woods, K. H. Gabbay, A. L. Nussbaum, J. S. Sussenbach, and J. L. Van der Brande. 1983. Sequence of cDNA encoding human insulinlike growth factor I precursor. Nature (Lond.). 306:609-611.

38. Whitfeld, H. J., C. B. Bruni, R. Frunzio, J. E. Terrell, S. P. Nissley, and M. M. Rechler. 1984. Isolation of a cDNA clone encoding rat insulin-like growth factor-II precursor. Nature (Lond.). 312:277280.

39. Ullich, A., A. Gray, A. W. Tam, T. Yang-Feng, M. Tsubokawa, C. Collins, W. Henzel, T. Le Bon, S. Kathuria, E. Chen, S. Jacobs, U. Francke, J. Ramachandran, and Y. Fujita-Yamaguchi. 1986. Insulin-like growth factor I receptor primary structure: comparison with insulin receptor suggests structural determinants that define functional specificity. EMBO (Eur. Mol. Biol. Organ.) J. 5:2503-2512.

40. Rechler, M. M., and S. P. Nissley. 1985. The nature and regulation of the receptors for insulin-like growth factors. Annu. Rev. Physiol. 47:425-442.

41. Hoppener, J. W. M., S. Mosselman, P. J. M. Roholl, C. Lam- 
brechts, R. J. C. Slebos, P. dePagter-Holthuizen, C. J. M. Lips, H. S. Jansz, and J. S. Sussenbach. 1988. Expression of insulin-like growth factor-I and -II genes in human smooth muscle tumours. EMBO (Eur. Mol. Biol. Organ.) J. 7:1379-1385.

42. Huff, K. K., D. Kaufman, K. H. Gabbay, E. M. Spencer, M. E. Lippman, and R. B. Dickson. 1986. Secretion of an insulin-like growth factor-I-related protein by human breast cancer cells. Cancer Res. 46:4613-4619.

43. Yee, D., S. Paik, G. S. Lebovic, R. R. Marcus, R. E. Favoni, K. J. Cullen, M. E. Lippman, and N. Rosen. 1989. Analysis of insulin-like growth factor I gene expression in malignancy: evidence for a paracrine role in Human Breast Cancer. Mol. Endocrinol. 3:509-517.

44. Morgan, D. O., J. C. Edman, D. N. Standring, V. A. Fried, M. C. Smith, R. A. Roth, and W. J. Rutter. 1987. Insulin-like growth factor II receptor as a multifunctional binding protein. Nature (Lond.). 329:301-307.

45. Roth, R. A. 1988. Structure of the receptor for insulin-like growth factor II: the puzzle amplified. Science (Wash. DC). 239:12691271.

46. Van Wyk, J. J., D. C. Graves, S. J. Casella, and S. Jacobs. 1985. Evidence from monoclonal antibody studies that insulin stimulated deoxyribonucleic acid synthesis through the type I somatomedin receptor. J. Clin. Endocrinol. Metab. 61:639-643.

47. Flier, J. S., P. Usher, and A. C. Moses. 1986. Monoclonal antibody to the type I insulin-like growth factor (IGF-I) receptor blocks IGF-I receptor-mediated DNA synthesis: clarification of the mitogenic mechanisms of IGF-I and insulin in human skin fibroblasts. Proc. Natl. Acad. Sci. USA. 83:664-668.

48. Furlanetto, R. W., J. N. DiCarlo, and C. Wisehart. 1987. The type II insulin-like growth factor receptor does not mediate deoxyribonucleic acid synthesis in human fibroblasts. J. Clin. Endocrinol. Metab. 64:1142-1149.

49. Conover, C. A., R. G. Rosenfeld, and R. L. Hintz. 1987. Insulin-like growth factor II binding and action in human fetal fibroblasts. J. Cell. Physiol. 133:560-566.

50. Ewton, D. Z., S. L. Falen, and J. R. Florini. 1987. The type II insulin-like growth factor (IGF) receptor has low affinity for IGF-I analogs: pleiotypic actions of IGFs on myoblasts are apparently mediated by the type I receptor. Endocrinology. 120:115-123.

51. Kiess, W., J. F. Haskell, L. Lee, L. A. Greenstein, B. E. Miller, A. L. Aarons, M. M. Rechler, and S. P. Nissley. 1987. An antibody that blocks insulin-like growth factor (IGF) binding to the type II IGF receptor is neither an agonist nor an inhibitor of IGF-stimulated biologic responses in L6 myoblasts. J. Biol. Chem. 262:12745-12751.

52. Casella, S. J., V. K. Han, A. J. D'Ercole, M. E. Svoboda, and J. J. Van Wyk. 1986. Insulin-like growth factor II binding to the type I somatomedin receptor. J. Biol. Chem. 261:9268-9273.

53. Helman, L. J., C. J. Thiele, W. M. Linehan, B. D. Nelkin, S. B. Baylin, and M. A. Israel. 1987. Molecular markers of neuroendocrine development and evidence of environmental regulation. Proc. Natl. Acad. Sci. USA. 84:2336-2339.

54. Haselbacher, G. K., J. C. Irminger, J. Zapf, W. H. Ziegler, and R. E. Humbel. 1987. Insulin-like growth factor II in human adrenal pheochromocytomas and Wilms tumors: expression at the mRNA and protein level. Proc. Natl. Acad. Sci. USA. 84:1104-1106.

55. Tricoli, J. V., L. B. Rall, C. P. Karakousis, L. Herrera, N. J. Petrelli, G. I. Bell, and T. B. Shows. 1986. Enhanced levels of insulinlike growth factor messenger RNA in human colon carcinomas and liposarcomas. Cancer Res. 46:6169-6173.

56. Yee, D., K. J. Cullen, S. Paik, J. F. Perdue, B. Hampton, A.
Schwartz, M. E. Lippman, and N. Rosen. 1988. Insulin-like growth factor II mRNA expression in human breast cancer. Cancer Res. 48:6691-6696.

57. Cariani, E., C. Lasserre, D. Seurin, B. Hamelin, F. Kemeny, D. Franco, M. P. Szech, A. Ullrich, and C. Brechot. 1988. Differential expression of insulin-like growth factor II mRNA in human primary liver cancers, benign liver tumors, and liver cirrhosis. Cancer Res. 48:6844-6849.

58. Hoppener, J. W. M., P. H. Steenbergh, R. J. C. Slebos, P. de Pagter-Holthuzen, B. A. Roos, M. Jansen, J. L. Van den Brande, J. S. Sussenbach, H. S. Jansz, and C. J. M. Lips. 1987. Expression of insulin-like growth factor-I and -II genes in rat medullary thyroid carcinoma. FEBS (Fed. Eur. Biochem. Soc.) Lett. 215:122-126.

59. Norstedt, G., A. Levinovitz, C. Moller, L. C. Eriksson, and G. Andersson. 1988. Expression of insulin-like growth factor (IGF-I) and IGF-II mRNA during hepatic development, proliferation and carcinogenesis in the rat. Carcinogenesis (Lond.). 9:209-213.

60. Ueno, T., K. Takahashi, T. Matsuguchi, K. Ikejiri, H. Endo, and M. Yamamoto. 1988. Reactivation of rat insulin-like growth factor II gene during hepatocarcinogenesis. Carcinogenesis (Lond.). 9:1779-1783.

61. Fu, X.-X., C. Y. Su, Y. Lee, R. Hintz, L. Biempica, R. Snyder, and C. E. Rogler. 1988. Insulinlike growth factor II expression and oval cell proliferation associated with hepatocarcinogenesis in woodchuck hepatitis virus carriers. J. Virol. 62:3422-3430.

62. Daughaday, W. H., M. A. Emanuele, M. H. Brooks, A. L. Barbato, M. Kapadia, and P. Rotwein. 1988. Synthesis and secretion of insulin-like growth factor II by a leiomyosarcoma with associated hypoglycemia. $N$. Engl. J. Med. 319:1434-1440.

63. Roth, J., W. Jr. Lowe, S. T. Fui, D. Arnold, R. Eastman, D. Le Roith, and H. Keen. 1987. Messenger RNA for IGF-II is increased in a hemangiopericytoma associated with hypoglycemia. Endocr. Soc. 664:187. (Abstr.)

64. Shapiro, T., K. Polonsky, M. Kew, A. Rubenstein, and G. Bell. 1988. Tumor hypoglycemia is associated with increased expression of the gene for insulin-like growth factor II. Clin. Res. 36:490A. (Abstr.)

65. Bell, G. I., J. P. Merryweather, R. Sanchez-Pescador, M. M. Stempien, L. Priestley, J. Scott, and L. B. Rall. 1984. Sequence of a cDNA clone encoding human preproinsulin-like growth factor II. $\mathrm{Na}$ ture (Lond.). 310:775-777.

66. Kiess, W., C. L. Thomas, L. A. Greenstein, L. Lee, M. M. Sklar, M. M. Rechler, G. G. Sahagian, and S. P. Nissley. 1989. Insulin-like growth factor-II (IGF-II) inhibits both the cellular uptake of beta-galactosidase and the binding of beta-galactosidase to purified IGF-II/ Mannose 6-phosphate receptor. J. Biol. Chem. 264:4710-4714.

67. Keating, M. T., and L. T. Williams. 1988. Autocrine stimulation of intracellular PDGF receptors in v-sis-transformed cells. Science (Wash. DC). 239:914-916.

68. Clemmons, D. R., and J. J. Van Wyk. 1985. Evidence for a functional role of endogenously produced somatomedin-like peptides in the regulation of DNA synthesis in cultured human fibroblasts and porcine smooth muscle cells. J. Clin. Invest. 75:1914-1918.

69. Maciel, R. M. B., A. C. Moses, G. Villone, D. Tramontano, and S. H. Ingbar. 1988. Demonstration of the production and physiological role of insulin-like growth factor II in rat thyroid follicular cells in culture. J. Clin. Invest. 82:1546-1553.

70. Irminger, J.-C., K. M. Rosen, R. E. Humbel, and L. Villa-Komaroff. 1987. Tissue-specific expression of insulin-like growth factor II mRNAs with distinct $5^{\prime}$ untranslated regions. Proc. Natl. Acad. Sci. USA. 84:6330-6334. 